() (1) https://creativecommons.org/licenses/by/4.0/

Privatização da e na educação infantil

\title{
ARTICULAÇÕES ENTRE O PÚBLICO E O PRIVADO NA EDUCAÇÃO DE INFÂNCIA EM PORTUGAL
}

\author{
EMÍLIA VILARINHO ${ }^{1}$ \\ ORCID: https://orcid.org/0000-0001-5760-3716
}

\begin{abstract}
RESUMO: O artigo aborda políticas de Educação de Infância em Portugal destacando o papel do Estado, quer como promotor de políticas públicas que tendem a consolidar o direito à educação, quer como favorecedor e impulsionador de dinâmicas de privatização da e na Educação de Infância. A partir da análise de documentos oficiais (1997-2018) e de um estudo de caso, a pesquisa revela que o Estado concebeu o sistema de Educação e Cuidado e definiu políticas e estratégias diferenciadas de provisão, financiamento e governação em relação às creches e aos jardins de infância. Indica ainda que, nas últimas décadas, as articulações entre o público e o privado são marcadas por orientações de pendor neoliberal e de terceira via que reformulam as redes existentes, consolidam parcerias, redefinem ou introduzem novos processos de regulação, de financiamento e potenciam a presença de novos atores privados. Finalmente, discutimos os efeitos dessas políticas no quadro dos direitos da criança, da democratização e da igualdade em educação.
\end{abstract}

Palavras-chave: Políticas de Educação de Infância, Igualdade em Educação, Público e Privado, Parcerias, Direitos da Criança.

\section{RELATIONSHIPS BETWEEN THE PUBLIC AND PRIVATE SECTORS OF EARLY CHILDHOOD EDUCATION IN PORTUGAL}

\begin{abstract}
This article deals with the policies of Early Childhood Education in Portugal, highlighting the role of the State both as a promoter of public policies that aim to consolidate the right to education, as well as an advocate and driving force of the privatization dynamics of Early Childhood Education. From the analysis of official documents (1997-2018) and a case study, the research reveals that the State devised the system Education and Care and set differentiated policies and strategies for the provision, funding and governance of nurseries and kindergartens. It also indicates that, over the past decades, the relationships between the public and the private sector have been marked by neoliberal and third-way orientations that aim to reformulate existing networks, consolidate partnerships, redefine or introduce new regulation and funding processes, and propel the presence of new private sector players. Finally, we discuss the effects of these policies on children's rights, the democratization and equality in education.
\end{abstract}

\footnotetext{
1 Instituto de Educação. Universidade do Minho. Centro de Investigação em Educação (CIEd). Braga, Portugal. evilarinho@ie.uminho.pt - Trabalho financiado pelo CIEd - UID/CED/01661/2019 através da FCT/MCTES-PT.
} 
Keywords: Early Childhood Education Policies, Education Equality, Public and Private, Partnerships, Rights of Child.

\section{VÍNCULOS ENTRE LO PÚBLICO Y LO PRIVADO EN LA EDUCACIÓN INFANTIL EN PORTUGAL}

RESÚMEN: El artículo analiza las políticas de Educación Infantil en Portugal, destacando el papel del Estado como promotor de políticas públicas que tienden a consolidar el derecho a la educación, así como un defensor e impulsor de la dinámica de privatización y en la educación de la primera infancia. A partir del análisis de documentos oficiales (1997-2018) e un caso de estúdio, el estudio revela que el Estado concibió el sistema de Educación y Cuidado y definió políticas y estrategias diferenciadas para la provisión, financiamiento y gobernanza en relación con jardines de infantes y jardines de infantes. También señala que en las últimas décadas las articulaciones entre lo público y lo privado han estado marcadas por orientaciones neoliberales y de tercera vía que reformulan las redes existentes, consolidan asociaciones, redefinen o introducen nuevas regulaciones, procesos de financiación y mejoran la presencia de Nuevos actores privados. Finalmente, discutimos los efectos de estas políticas sobre los derechos del niño, la democratización y la igualdad en la educación.

Palabras clave: Políticas de Educación Infantil, Igualdad en la Educación, Asociaciones, Derechos del Niño.

\section{INTRODUÇÃO}

Este artigo resulta de uma investigação em curso que pretende dar continuidade à análise sociológica das políticas de Educação Pré-Escolar ${ }^{2}$ que temos vindo a desenvolver (1977/2010), com principal enfoque na discussão do papel do Estado na definição da educação de infância, na promoção de políticas educativas para crianças dos 3 aos 6 anos e a sua relação com a promoção da igualdade em educação e com os direitos da criança.

Nesta investigação, ampliamos o recorte temporal para 2018 e incorporamos a análise das políticas de atendimento às crianças dos 0 aos 3 anos de idade ${ }^{3}$. Mobilizamos o conhecimento produzido no campo da análise sociológica das políticas educativas, das sociologias da educação e da infância, com o intuito de compreender as novas estratégias do pós-Estado providência de regulação e governação da educação, o papel da sociedade civil (Mercado e Comunidade) nesses processos e as implicações dessas mudanças.

A abordagem investigativa é de caráter qualitativo, e o método é o estudo de casos múltiplos. O projeto desenvolve-se em duas fases: na primeira, recorrendo à análise documental, será feita a atualização do mapeamento das políticas e a discussão do quadro normativo-legal, programas, relatórios, estatísticas; na segunda fase, através da observação não participante e da entrevista, retoma-se a análise do município estudado até 2010 e integram-se na pesquisa outros dois da mesma região.

O seu objetivo geral é compreender a expressão das novas estratégias do pós-Estado providência de regulação e governação de educação nas políticas de Educação de Infância, ao nível da provisão, do conteúdo e da governação. Especificamente, interessa-nos interrogar: como as políticas estão a ser apropriadas e reinterpretadas no contexto da prática (Bowe, Ball \& Gold, 1992) e que efeitos estão a produzir; que atores (institucionais/individuais) são envolvidos, como participam, que lógicas e interesses presidem à sua ação; que combinações/arranjos institucionais são criados para a

\footnotetext{
${ }^{2}$ É o termo oficial utilizado em Portugal para designar o atendimento institucional das crianças dos 3 aos 6 anos, idade de ingresso no ensino básico obrigatório. É realizado em jardins de infância (escolas infantis) e é da responsabilidade de educadores de infância (professores habilitados com formação superior especializada - grau de mestre).

${ }^{3}$ Este atendimento é realizado em creches e, a partir dos 12 meses, tem um educador de infância por sala. Educação em Revista|Belo Horizonte|v.36|e231420|2020
} 
implementação das políticas; que fatores e atores têm influenciado a definição do conteúdo da educação de infância.

$\mathrm{O}$ artigo estrutura-se em duas partes. $\mathrm{Na}$ primeira, numa perspectiva diacrônica, identificamos as principais medidas de intervenção do Estado, sinalizando a forma como este foi redefinindo o seu papel e construindo a agenda para este nível de educação através da legislação e documentos oficiais relevantes publicados em diferentes ciclos políticos, após $1974^{4}$. Dada a centralidade da Lei-Quadro da Educação Pré-Escolar, lei n. ${ }^{\circ}$ 5/97 de 10 de fevereiro, dos decretos que a regulamentaram (em particular, o decreto-lei n. ${ }^{\circ}$ 147/97, de 11 de junho) e do Plano de Expansão e Desenvolvimento da Educação Pré-Escolar (PEDEPE) que a implementou, daremos maior destaque à análise a partir desse período.

$\mathrm{Na}$ segunda parte, tomando como referência os eixos estratégicos de desenvolvimento das políticas pré-escolares, identificados em investigação anterior (Vilarinho, 2011), e a partir da análise de estatísticas e de relatórios, bem como recuperando dados recolhidos através de um estudo de caso realizado no norte de Portugal, identificamos modalidades, processos, "arranjos institucionais" que dão conta de articulações entre o público e o privado e de dinâmicas de privatização da e na ${ }^{5}$ educação de infância.

\section{POLÍTICAS DE EDUCAÇÃO DE INFÂNCIA EM PORTUGAL: HIDRIDISMOS E TENSÕES ENTRE O PÚBLICO E O PRIVADO}

Em Portugal, a infância emerge como questão social importante a partir do fim do século XIX e do início do século XX, quando, então, proteger, cuidar e educar as crianças passou a ser gradualmente assumido como um dever do Estado. As diferentes conjunturas sociopolíticas que se foram sucedendo e os discursos produzidos acerca delas (Vilarinho, 2000) marcaram as políticas, a definição desse grupo geracional e redefiniram funções e conceções da sua educação. Como os estudos sociológicos vão esclarecendo, o processo de institucionalização da infância (Nasman, 1994), no que se refere à instituição escolar, vai de forma lenta expandindo-se "para baixo", através da criação de creches e de jardins de infância. Esta expansão integra em si tensões entre diferentes perspetivas de olhar a criança (Hendrix, 1990) e vai definindo a pequena infância e a sua educação (Chamboredon \& Prévot, 1982). Inicia-se um processo mundial de administração simbólica da infância, alicerçado na normatividade (Marchi \& Sarmento, 2017), com expressões diferentes em cada país, que vai regulando, domesticando as crianças e "padronizando o que elas aprendem e como aprendem" (Prout, 2010:30).

A partir da segunda metade do século XX, observam-se tendências que disputam entre si: políticas para a promoção da igualdade de gênero no acesso ao emprego e de incentivo à natalidade e políticas centradas no desenvolvimento infantil, na promoção da igualdade de oportunidades educativas (Vilarinho, 2000) e na criança como sujeito de direitos (Fernandes, 2009).

Em Portugal, a definição das políticas de educação de infância tem sido atravessada por estas tensões, às quais se têm paulatinamente associado outras, como as que decorrem da tendência para uma escolarização da educação da pequena infância (Garnier, 2016; Halldén, 2012; Bassok, Latham \& Rorem, 2016; Losso \& Marcchi, 2011), que se inscreve num quadro mais global de políticas de regulação centradas nos resultados.

Numa perspetiva diacrônica e organizada por referência à tipologia que fomos construindo (Vilarinho, 2000, 2011), apresentamos e discutimos as fases e os principais instrumentos normativos que configuram a política de educação de infância em Portugal.

\section{Fase da Criação, Normalização e Expansão (1977/1986)}

\footnotetext{
${ }^{4}$ Ano em que se iniciou o processo de democratização do País.

${ }^{5}$ Dinâmicas aqui entendidas como: privatização da - alteração da propriedade, ocorrendo da passagem do estatal para o terceiro setor ou privado ou através de parcerias público-privadas; privatização na - manutenção da propriedade estatal, mas em que é incorporada uma lógica de mercado nos processos de gestão e de (re)definição do conteúdo da política. 
Após a Revolução de 25 de Abril de $1974^{6}$, surge uma grande pressão social para a criação de políticas e de contextos formais de apoio à infância. Entre 1974 e 1976 foram introduzidas medidas que não só reforçaram as incipientes políticas sociais existentes, como estas ganharam uma nova centralidade política e jurídica ao assumir a proteção social como um direito universal.

É com a publicação da lei $n .^{\circ} 5 / 77$, de $1 .^{\circ}$ de fevereiro, que se inaugura um novo ciclo na Educação Pré-Escolar (EPE). Dando expressão aos princípios da nova Constituição Portuguesa (1976), a referida lei criou o sistema público gratuito da EPE, permitindo a criação de jardins de infância públicos e a expansão da sua rede pelo País. Com a sua publicação, o Estado português procurou dar corpo aos ideais da democratização do ensino, do princípio da igualdade de oportunidades em educação e ao direito das crianças à educação laica e gratuita. A sua frequência tem "caráter facultativo e destina-se às crianças desde os três anos até à idade de entrada no ensino primário" (artigo $2^{\circ}$ ).

Todavia, é criado um sistema que apenas abrange uma parte da infância. A designação de Educação Pré-Escolar ganhou centralidade na redefinição da educação das crianças pequenas ( 0 aos 6 anos) e marca a arquitetura sociojurídica e organizacional desse sistema. Aquela lei produz efeitos a vários níveis: na (re)definição da infância, no conteúdo e nas funções dos serviços para as crianças, na organização da rede e no papel assumido pelo Estado e por outras entidades. Ao limitar a frequência a crianças dos 3 anos até à idade de ingresso na escola primária ${ }^{7}$, reforça-se o recorte de idades na pequena infância: a idade-bebê ( $0-3$ anos) e a idade pré-escolar (3-6 anos), sendo estas entendidas como sujeito pré-cultural e sujeito cultural (Chamboredon \& Prévot, 1982), respectivamente.

Este recorte de idades justificou a existência de serviços para a infância diferenciados que se orientam para dar resposta às diferentes necessidades das crianças e das suas famílias. A creche assume essencialmente uma função de guarda e de cuidados dos bebês; e o jardim de infância, uma função educativa e de desenvolvimento integral das crianças. Esta lei configurou a diversidade conceptual e organizacional dos serviços para a infância. Essa diversidade das redes pública e privada era visível nas diferenças de funcionamento dos estabelecimentos (horários, interrupções e períodos de encerramento anual) e nos salários e estatutos dos profissionais de educação de infância. $\mathrm{O}$ tempo de funcionamento reduzido dos jardins de infância da rede pública introduziu uma desigualdade no acesso, particularmente nas crianças dos meios urbanos e de zonas mais industrializadas, onde o horário laboral dos pais era incompatível com esse regime. Com a publicação do Estatuto dos Jardins de infância - decreto-lei n. ${ }^{\circ}$ $542 / 79$, de 31 de dezembro, inicia-se um processo de normalização e controle de todas as iniciativas préescolares públicas e privadas. O Ministério da Educação assume o apoio à expansão e à tutela dos jardins de infância públicos, e o Ministério do Trabalho e Segurança Social promove a diferenciação das ofertas para as crianças dos 0 aos 6 anos da rede privada não lucrativa, assumindo a sua tutela e a comparticipação no financiamento. É neste quadro de diversificação que é reforçado o papel das instituições que prestavam atendimento à infância (misericórdias, centros paroquiais, instituições religiosas, instituições comunitárias, entre outras) como complementares das iniciativas públicas.

Nesse mesmo período, o decreto-lei n. ${ }^{\circ} 119 / 83$, de 25 de fevereiro, que aprova os Estatutos das Instituições Particulares de Solidariedade Social (IPSS), constitui-se como um instrumento fundamental para a explicitação da relação entre o Estado e as instituições privadas, no que concerne à sua intervenção nas áreas da proteção social. A partir desse momento, as IPSS assumiram um papel relevante na implementação da rede de creches e de jardins de infância, respondendo à forte procura social daqueles serviços, particularmente em zonas urbanas de grande densidade populacional.

A forte pressão social, motivada pela procura de conciliação do trabalho com a vida familiar, impulsionou a criação de novas creches e de outras modalidades de atendimento às crianças dos 0 aos 3 anos, como as amas licenciadas e as creches familiares. Os centros distritais de segurança social passam a regular técnica e financeiramente uma atividade que até esse momento era clandestina.

Os dados estatísticos revelam que nesse período se operou a expansão da rede pública da EPE, assumindo o Estado um papel de promotor direto de jardins de infância públicos. A expansão desta rede teve em conta critérios de discriminação positiva de regiões do País onde as taxas de insucesso

\footnotetext{
${ }^{6}$ Revolução que derrubou o regime ditatorial vigente desde 1933.

7 Termo usado na época para designar a escola do $1 .^{\circ}$ ciclo do ensino básico (ensino fundamental no Brasil). Educação em Revista|Belo Horizonte|v.36|e231420|2020
} 
escolar eram mais elevadas, o que na nossa leitura é um indicador de pendor democrático desta política e de valorização da função educativa dos jardins de infância. Todavia, este critério veio a contribuir para o aumento da rede nos meios rurais e para as assimetrias de cobertura da mesma, uma vez que não foi acompanhado de um movimento de expansão contínuo, como veremos no período seguinte.

Relativamente ao atendimento às crianças dos 0 aos 3 anos, o Estado assume dominantemente o papel de mobilizador e de regulador de iniciativas privadas. Assim, não há uma ruptura com as políticas de privatização iniciadas na década anterior. A particularidade nesse período parece residir em um apoio mais explícito e efetivo às iniciativas privadas sem fins lucrativos (organizações do terceiro setor), algumas delas já existentes na ditadura, outras criadas por movimentos associativos no período revolucionário - 1974-1976 (Stoer, 1986). Este descomprometimento do Estado pela criação de estabelecimentos públicos vai permitir uma expansão muito significativa do privado pelo País, que se organiza criando instituições que integram creches e jardins de infância. Dessa forma, acentuam-se as desigualdades de acesso às crianças a um atendimento socioeducativo, marcado não só pela classe social de origem, pelo rendimento familiar, pela área geográfica, mas também pelo recorte de idade na primeira infância.

\section{Fase de retração $(1986 / 1995)$}

A segunda metade da década de 1980 é marcada pelas discussões em torno da Reforma Educativa, e o debate da educação de infância constrói-se ancorado a preocupações com a promoção do sucesso educativo. É desenvolvida toda uma narrativa defendendo uma orientação educativa e uma função compensatória das desigualdades culturais e sociais experienciadas pelas crianças mais pobres e do interior do País. Todavia, esse debate não terá expressão no alargamento da rede de jardins de infância, verificando-se uma retração do movimento iniciado no fim da década de 1970 (Vilarinho, 2000).

A publicação da Lei de Bases do Sistema Educativo - lei n. ${ }^{\circ}$ 46/86, de 14 de outubro - é um marco importante para a EPE porque reforça a sua função educativa e mantém a sua autonomia em relação aos ciclos subsequentes (art. $5^{\circ}$, n. ${ }^{\circ}$ 1.) No entanto, esta lei não integra a educação das crianças até aos 3 anos, e assim a creche continua a ser tutelada pelo Ministério do Trabalho e da Solidariedade Social e concebida como "resposta social, desenvolvida em equipamento, de natureza socioeducativa, para acolher crianças até aos três anos de idade, durante o período diário correspondente ao impedimento dos pais ou da pessoa que tenha a sua guarda de facto, vocacionado para o apoio à criança e à família" (Despacho Normativo n..$^{\circ}$ 99/89, de 11 de setembro).

Pela primeira vez, neste nível educativo, admite-se no discurso oficial a possibilidade de o Estado celebrar contratos com parceiros educativos:

\footnotetext{
"Aqui, como noutras áreas, o Estado pode surgir como grande impulsionador, celebrando contratos de educação infantil com entidades que dinamizem e assumem a gestão quanto a centros de educação da primeira infância" (Relatório da Comissão de Reforma do Sistema Educativo: 104).
}

O que importa salientar é a emergência de uma prática discursiva que, lentamente, legitima a alteração do papel do Estado de promotor a mobilizador e regulador, fortemente relacionada com o lema neoliberal "menos Estado, melhor Estado". Dado o carácter facultativo da EPE e as tensões sempre latentes entre as funções educativa e de guarda, o Estado não investiu na rede pública e aguardou pela expansão das iniciativas privada e de solidariedade social, que sempre serviram de "tampão" ao dever do Estado. Registra-se um descomprometimento do Estado face ao desenvolvimento das políticas educativas pré-escolares, o que indica um incumprimento das disposições constitucionais.

Durante esse período, e na regência do XII Governo (Partido Social Democrata), a publicação do Parecer n. ${ }^{\circ}$ 1/94 do Conselho Nacional de Educação sobre a Educação Pré-Escolar em Portugal assumiu um papel relevante na tomada de consciência do estado da arte desse nível de educação, ao fazer um diagnóstico crítico da situação portuguesa. Recomendou medidas urgentes na resolução dos seus principais problemas, entre eles, as assimetrias regionais de cobertura da rede e o maior peso da rede particular e cooperativa. Nessa legislatura, é publicado o decreto-lei n. ${ }^{\circ}$ 173/95, de 20 de julho, que 
"define o regime de atribuição pelo Ministério da Educação de apoios financeiros à criação e manutenção de estabelecimentos de Educação Pré-Escolar", incentivando a criação e a manutenção de jardins de infância através de contratos-programa com diversas entidades educativas: autarquias, instituições de solidariedade social, fundações, cooperativas e instituições privadas. Esse diploma é inspirado no ideário neoliberal e criou as condições para a privatização e para a emergência de um mercado educacional nesse nível educativo. Assim, o referido decreto distanciava-se dos ideais democráticos da construção de uma rede pública, universal, gratuita e laica, enquanto expressão da consagração dos direitos da criança à educação. $\mathrm{O}$ papel do Estado é redefinido de promotor a mobilizador e regulador. $\mathrm{Na}$ apresentação à comunicação social de tal medida legislativa, Cavaco Silva (primeiro ministro, na época) esclareceu qual o papel do Estado no desenvolvimento daquela rede: "o Estado deve estimular e apoiar financeiramente o pré-escolar, não assumindo, no entanto, a tarefa de criação e gestão directa dos novos estabelecimentos" (Jornal de Notícias, 12 de abril de 1995).

\section{Fase de revitalização $(1995 / 1997)$}

Durante a vigência do XIII Governo (Partido Socialista), foi publicada a Lei-Quadro da Educação Pré-Escolar - lei n. ${ }^{\circ}$ 5/97, de 10 de fevereiro (LQEPE). Essa lei-quadro cria os alicerces de um novo projeto político-educativo e define a agenda para a resolução dos problemas ${ }^{8}$ identificados nos pareceres e estudos anteriormente elaborados, nomeadamente no Parecer n. ${ }^{\circ} 1 / 94$ do Conselho Nacional de Educação, no Plano de Desenvolvimento a Quatro Anos da Educação Pré-Escolar (1993) e no Relatório Estratégico para a Expansão e Desenvolvimento da Educação Pré-Escolar (1996). A lei-quadro consagra algumas conquistas ao nível dos direitos das crianças à EPE e da clarificação conceptual e organizativa desse nível de educação.

No que concerne à sua concepção e objetivos, salientamos os seguintes aspectos: reforça a função educativa com a assunção da EPE como "a primeira etapa da educação básica no processo de educação ao longo da vida" (artigo $2^{\circ}$ ); reafirma o papel da EPE na promoção do sucesso educativo das crianças, a sua função compensatória das desigualdades sociais, propondo a universalização da oferta; consagra a gratuitidade da componente educativa em todos os estabelecimentos pré-escolares, sejam eles de natureza pública, privada ou de solidariedade social (ponto 1 , artigo $16^{\circ}{ }^{\circ}$ ) . No âmbito da rede e princípios organizativos: cria a rede nacional de EPE, que passa a ser constituída pela rede pública e pela rede privada ${ }^{10}$; define o novo modelo organizativo desses estabelecimentos - "instituição que presta serviços vocacionados para o desenvolvimento da criança, proporcionando-lhe atividades educativas, e atividades de apoio à família" (artigo 3. ${ }^{\circ}$, ponto 3$)^{11}$; define um novo horário de funcionamento para os jardins de infância públicos, de modo que esse seja adequado ao desenvolvimento de atividades educativas, de animação e de apoio à família (artigo 12. ${ }^{\circ}$, pontos 1 e 2), permitindo, dessa forma, o alargamento do horário de atendimento das crianças nesses jardins ${ }^{12}$.

\footnotetext{
${ }^{8}$ A desarticulação interministerial, a fragmentação institucional e sociojurídica derivada da diversidade de promotores e de diferentes tutelas ministeriais, a predominância da função assistencial sobre a educativa nos jardins de infância da rede privada, a baixa taxa de cobertura nacional, as assimetrias regionais de oferta e, consequentemente, as desigualdades de acesso das crianças à Educação Pré-Escolar (Vilarinho, 2000).

${ }_{9}^{9}$ Determina que a aplicação desta medida se inicia no ano letivo de 1997/1998 para as crianças que tenham completado 5 anos de idade e que deverá ser alargada progressivamente às restantes idades até ao ano letivo de 2000/2001 (artigo 23. ${ }^{\circ}$, ponto 2).

${ }^{10}$ Ensino particular e cooperativo, instituições particulares de solidariedade social e outras instituições sem fins lucrativos (art.14).

${ }^{11}$ Este novo modelo organizacional integra duas componentes: i) Componente educativa que corresponde ao tempo de 25 horas exclusivamente dedicado ao trabalho de natureza curricular da responsabilidade de um educador de infância ii) Componente socioeducativa, designada por Componente de Apoio à família (CAF), que diz respeito ao restante tempo de permanência das crianças nas instituições e integra atividades de acolhimento, tempos livres e serviço de refeições. Esta componente deve ser coordenada por educadores de infância e desenvolvida por outros técnicos de educação (animadores e educadores sociais, técnicos de apoio social).

${ }^{12}$ Com esta medida, os jardins de infância públicos passam também a assumir a função social de apoio às famílias, integrando os serviços de refeição e de tempos de acolhimento, animação das crianças, que até então eram apenas prestados nos jardins da rede privada.
} 
No que concerne ao papel do Estado (na constituição da rede e no financiamento), esta lei introduz uma orientação próxima das políticas de terceira via (Vilarinho, 2011, 2015), ao propor a mobilização da sociedade civil para a expansão da oferta e ao criar (formalmente) as condições para a gratuitidade da componente educativa na rede privada não lucrativa. Assim: i) assume o dever do Estado de "criar uma rede pública de Educação Pré-Escolar, generalizando a oferta dos respectivos serviços, de acordo com as necessidades" (alínea a) do artigo 5. e de "apoiar a criação de estabelecimentos de Educação Pré-Escolar por entidades da sociedade civil, na medida em que a oferta disponível seja insuficiente" (alínea b) do artigo . $^{\circ}$; ii) define os critérios a serem adotados para a concretização da gratuitidade da componente educativa e da componente de apoio à família (artigo 22..$^{\circ}$ ) e prevê que o Estado possa comparticipar os custos desta última componente às famílias com necessidades socioeconômicas (artigo 16. ${ }^{\circ}$, ponto 2); iii) consagra a tutela pedagógica e técnica, a criação de mecanismos de supervisão, avaliação e de financiamento da rede, a definição de critérios de avaliação da qualidade dos serviços prestados, o controle do funcionamento pedagógico e técnico dos jardins de infância (artigos 20..$^{\circ}$ e 21. ${ }^{\circ}{ }^{13}$. A assunção da tutela pedagógica pelo Ministério da Educação é reforçada pelas Orientações Curriculares para a Educação Pré-Escolar (OCEPE), publicadas no Despacho n. ${ }^{\circ}$ 5220/SEEI/97, de 4 de agosto.

O Decreto-Lei n. ${ }^{\circ}$ 147/97, de 11 de junho, estabeleceu o ordenamento jurídico do desenvolvimento e expansão da rede nacional de EPE. Este decreto criou as bases para o lançamento efetivo do Programa de Expansão e Desenvolvimento da Educação Pré-Escolar (PEDEPE). Dos enunciados deste decreto-lei ressaltam duas grandes prioridades governamentais: o alargamento das taxas de pré-escolarização e a promoção da qualidade dos serviços. Ao nível organizacional, é reforçada a perspetiva do modelo integrado de educação e cuidados, e os jardins de infância são concebidos como serviços socioeducativos de resposta às necessidades das crianças e das suas famílias. A partir da publicação daquele decreto-lei, o Estado vai reforçar o seu poder regulador, criando, sucessivamente, instrumentos de regulação institucional de cunho jurídico-burocrático em áreas como a edificação, a organização pedagógica, o apetrechamento de equipamentos e materiais pedagógicos para as salas de atividades dos jardins de infância, o currículo, entre outros.

Com relação às políticas de atendimento das crianças com idades entre os 0 e os 3 anos, observa-se uma orientação semelhante de promoção da qualidade dos serviços. O Guião Técnico n. ${ }^{\circ} 4$ - Creche (Direção Geral da Ação Social, 1996) - é um exemplo desta orientação, que se consolida nos períodos seguintes.

\section{Segunda Fase de expansão e de normalização (1999/2005)}

Esta fase é marcada pela implementação do PEDPE, que assenta na concepção de Rede Nacional definida no período anterior, razão pela qual a expansão tem em conta as ofertas pública e privada. Assim, pela contratualização, consolida-se a diversificação da provisão em detrimento da expansão pela rede pública. Para a expansão da oferta da rede privada solidária e para a implementação da Componente de Apoio à Família (CAF) nos jardins de infância públicos, são celebrados Protocolos de Cooperação Tripartidos, entre a Administração Central - Ministérios da Educação (ME) e do Trabalho e da Solidariedade (MTS) -, a Associação Nacional dos Municípios Portugueses (ANMP), a União das Instituições de Solidariedade Social (UIPSS), a União das Mutualidades (UP) e a União das Misericórdias Portuguesas (UMP). Verifica-se um aumento da oferta, mas observa-se a emergência de novas desigualdades de acesso aos jardins de infância, pela ausência de mecanismos eficazes de regulação e de monitorização do cumprimento dos referidos protocolos, como iremos destacar no ponto seguinte.

Nesta fase, o Estado fortalece o quadro normativo e, simultaneamente, implementa programas de incentivos financeiros às entidades privadas não lucrativas, reforçando assim o seu papel de regulador, financiador e avaliador. O financiamento fica condicionado ao cumprimento da legislação. A prioridade no financiamento é dada aos critérios de qualidade de natureza estrutural e processual (cf.

\footnotetext{
${ }^{13}$ Implementação de orientações curriculares, do Programa de Avaliação Integrado, de orientações para a edificação dos edifícios, organização pedagógica e materiais das salas de atividades, entre outros. 
Bertram \& Pascal, 1997; Dahlberg, Moss \& Pence, 2003), nomeadamente no apoio à construção de novos estabelecimentos, na aquisição de material didático-pedagógico, na revalorização salarial e no apoio ao recrutamento de educadores de infância. O Estado, ao legislar sobre esse conjunto de matérias, vai assumir um maior controle neste nível de educação, reforçando a sua presença na rede privada, em que foram diagnosticados alguns problemas, como a existência de mais de 25 crianças por sala em $30 \%$ dos jardins de infância privados e em $8 \%$ dos privados não lucrativos e a baixa quantidade e qualidade dos materiais educativos (Bairrão, 1999).

Relativamente às creches, não se observaram mudanças significativas na orientação política da concepção e gestão da sua rede.

\section{Fase de consolidação e do discurso da qualidade (2005/2011)}

Neste período, a agenda política contempla os critérios de qualidade de natureza processual, através de uma estratégia que combina a regulação institucional com a regulação exercida, de forma deferida, a partir da difusão do conhecimento. Para os jardins de infância, a publicação da Circular n. ${ }^{\circ}$ 17/DSDC/DEPEB $/ 2007^{14}$, do Despacho n. ${ }^{\circ}$ 14460/2008, de 26 de maio ${ }^{15}$, assim como a publicação de livros e brochuras de apoio editados pelo Ministério da Educação, são exemplos dessa estratégia. Este método de incentivo à promoção da qualidade é também visível na Creche. A publicação, em 2005, do Modelo de Avaliação da Qualidade das Respostas Sociais proposto pelo Instituto de Segurança Social dá conta desta tendência.

No entanto, importa questionar as concepções de qualidade que atravessam este modelo, uma vez que é mais visível uma orientação prescritiva, centrada na organização de procedimentos (de natureza organizativa e contratual), com orientação para o "cliente", do que sociopedagógica. Este modelo surge num tempo em que o discurso da "qualidade", marcado pelas orientações da "nova gestão pública", aparece como redentor e, simultaneamente, como referencial para práticas organizacionais. A Portaria n..$^{\circ}$ 262/2011, de 31 de agosto, introduz novas condições de funcionamento e de instalações das creches que espelham cedências aos interesses das entidades privadas (por exemplo, o aumento do número de crianças por sala e a não obrigatoriedade da presença de um educador no berçário (0-1 ano), mas consolida a creche como um equipamento de natureza socioeducativa.

Este último aspecto pode ser o primeiro passo para o reforço da intencionalidade educativa da creche, reclamada na Recomendação n. ${ }^{\circ}$ 3/2011 do Conselho Nacional de Educação. É também visível um movimento de expansão da oferta. O Programa de Alargamento da Rede de Equipamentos Sociais (PARES), publicado pela Portaria n. ${ }^{\circ} 426 / 2006$, foi o instrumento financeiro para Portugal, em 2009, atingir 34,9\% de cobertura de creche, ultrapassando assim a média europeia. Todavia, esta expansão continua a ser feita exclusivamente pela rede privada, sendo a solidária a que tem maior expressão. Relativamente à expansão dos jardins de infância, a lei $\mathrm{n}^{\circ} .85 / 2009$, de 27 de agosto ${ }^{16}$, consagra a universalidade da EPE para as crianças a partir dos 5 anos, criando as expectativas do aumento da oferta.

\section{Fase de universalização da oferta e de (re)definição da Educação de Infância (2011 /...)}

O estudo realizado até ao momento permite-nos, provisoriamente, afirmar que se esboçam duas tendências nas políticas de EI: a expansão da oferta e a redefinição do seu conteúdo.

A política de expansão da rede de creches é cada vez mais reclamada como fundamental para minimizar um problema estrutural do País, que é a queda acentuada da natalidade. É um tema na agenda, mas que não teve ainda expressão, particularmente na opção política de criação de uma rede pública. À semelhança do que acontece noutros países, o debate em torno da universalização ou obrigatoriedade da EPE ganha, neste período, alguma visibilidade. A opção governamental tem sido o alargamento da

\footnotetext{
14 Gestão do Currículo na Educação Pré-Escolar. Contributos para a sua operacionalização.

${ }^{15}$ Define as normas a observar na oferta das atividades de enriquecimento curricular e de animação e de apoio à família (1. ${ }^{\circ}$ Ciclo do Ensino Básico e EPE).

${ }^{16}$ Define o regime de escolaridade obrigatória.
} 
universalização. A lei n. ${ }^{\circ}$ 65/2015, de 3 de julho, alarga a universalização para as crianças de 4 anos. Importa acompanhar como esta tendência se vai materializando, nomeadamente se ela vai reforçar a democratização do acesso a este bem educativo pelo alargamento da rede pública.

No que se refere ao conteúdo, a publicação das novas Orientações Curriculares para a EPE, em 2016, vem reafirmar o caráter holístico do currículo, a concepção das crianças como sujeitos ativos nos processos de aprendizagem, clarifica a concepção de avaliação (para a melhoria das aprendizagens e não para os resultados) e assume fundamentos e princípios que devem estruturar a pedagogia da primeira infância (0-6 anos). Apesar desta orientação de pendor democrático e respeitadora da criança, observamse pressões que, inspiradas em visões mais utilitaristas da educação, vão redefinindo o que se deve "aprender" no jardim de infância, e criando nas famílias novas expectativas em torno das suas finalidades. Há um conjunto de novas expressões (ensino pré-escolar, aluno do pré-escolar, turma) que têm entrado acriticamente no vocabulário que está associado a este nível de educação e que ilustra os novos sentidos que lhe estão a ser atribuídos.

\section{ARTICULAÇÕES ENTRE O PÚBLICO E O PRIVADO: PROVISÃO, CONTEÚdO E GOVERNAÇÃO}

$\mathrm{Na}$ investigação desenvolvida (Vilarinho, 2011), a partir da análise do conjunto de documentos e normativos, dos discursos e depoimentos de responsáveis políticos, identificamos três eixos estratégicos de desenvolvimento das políticas de EPE: 1. A reorganização da rede e a expansão da oferta; 2. A redefinição da concepção - a consolidação da Educação Pré-Escolar como primeira etapa da Educação Básica e como serviço básico de apoio à família; 3. A redefinição do modelo organizacional - a implementação do modelo integrado de atendimento (Educação e Cuidado) e a promoção da qualidade.

Neste ponto, centraremos o nosso foco na análise de modalidades e de processos que ilustram as articulações entre o público e o privado, ao nível da provisão, do conteúdo e da governação (Dale 2005) da educação de infância. Retomando alguns dados da pesquisa terminada em 2011 e a análise de relatórios da Inspeção Geral de Ensino e Cultura e de estatísticas oficiais até ao momento produzidas, procuramos interrogar o desenvolvimento das medidas políticas implementadas e os efeitos que têm produzido, a partir dos três eixos identificados.

\section{Provisão: A expansão da oferta e as desigualdades de acesso}

\section{Creches}

A rede de creches em Portugal continental é privada e assegurada por entidades com e sem fins lucrativos. O Estado, através de Acordos de Cooperação, comparticipa financeiramente as entidades não lucrativas, e as famílias assumem o pagamento de um valor mensal para a frequência. De acordo com a Carta Social 2018 (GEP-MTSSS, 2019:22) ${ }^{17}$, em 2018, a taxa de cobertura média das creches e amas era de 48,4\%, registrando-se um crescimento de $82 \%$ entre 2006 e 2018 . Essa taxa ultrapassou a meta de 33\% fixada para assegurar o acolhimento das crianças com menos de 3 anos até 2010, pelo Conselho Europeu na Cimeira de Barcelona, realizada em 2002.

Figura 1 - Evolução da taxa de cobertura das respostas sociais para a 1. ${ }^{a}$ infância, 2006-2018.

\footnotetext{
${ }^{17}$ Dados relativos a Portugal Continental, não incluindo as Regiões Autônomas da Madeira e dos Açores. 


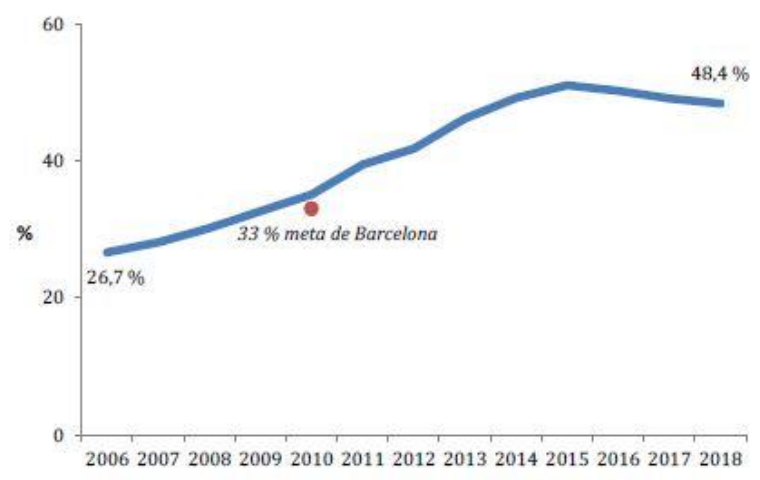

Fonte: GEP-MTSSS, Carta Social (2019:26).

O número de creches existentes, em 2018 , era de 2.570 , sendo $76,3 \%$ propriedade da rede não lucrativa e $23,7 \%$ da rede lucrativa. O número de lugares era de 117.330 , aproximadamente, sendo $63 \%$ da rede não lucrativa e 37\% da rede lucrativa (ibidem: 22-23). Este dado permite ver que a diferença da percentagem entre as duas redes é menor, objetivando a realidade do número de crianças que frequentam a creches sem qualquer apoio estatal ${ }^{18}$. As taxas de cobertura e de utilização têm aumentado nas duas redes, como podemos verificar na figura 2, apresentando a rede não lucrativa uma taxa de utilização média de 87,9\%. (ibidem: 27).

Figura 2 - Evolução da taxa de cobertura e da taxa de utilização das respostas sociais para a 1. ${ }^{a}$ infância segundo a natureza jurídica da entidade proprietária, 2005-2018.

Fonte: GEP-MTSSS, Carta Social (2019:28).

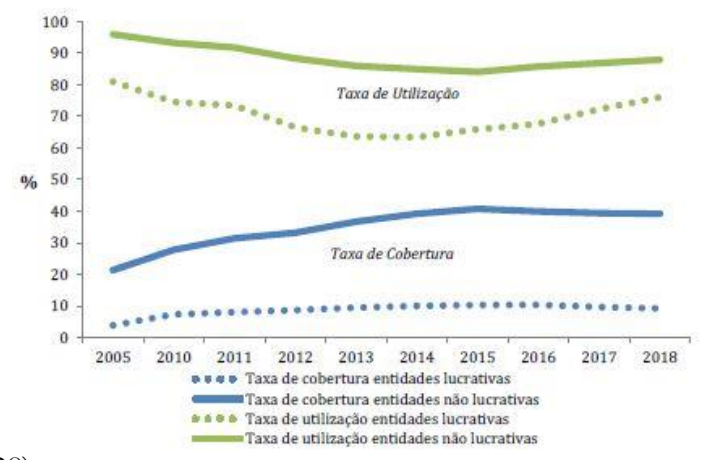

Apesar deste aumento, a distribuição territorial da oferta é desigual. Nas áreas metropolitanas de Lisboa e Porto, nomeadamente nos distritos de Lisboa, Setúbal e Porto, a oferta continua a registrar uma taxa de cobertura baixa, tendo em conta a população residente: $41 \%$, 44\% e 32\%, respectivamente. Nesses distritos, a rede lucrativa registra um peso relativo superior a 30\% (ibidem: 25). Considerando que a procura é marcada pela necessidade de conciliar a vida familiar com os horários de trabalho, a ausência de creches públicas tem produzido dinâmicas de oferta desiguais. Esta ausência potencia lógicas de mercado bem visíveis na distribuição geográfica das entidades privadas lucrativas que privilegiam territórios com densidade populacional elevada e tendencialmente com mais oferta de trabalho. Nesse sentido, a rede não lucrativa cumpre melhor o sentido social de proximidade às necessidades das crianças e famílias.

O Estado mantém a tendência de assumir os papéis de regulador e de impulsionador da oferta, e não de promotor direto do atendimento das crianças dos 0 aos 3 anos. Ao não garantir o acesso

\footnotetext{
${ }^{18}$ Nas entidades não lucrativas, porque apoiadas financeiramente pelo Estado, o valor das mensalidades cobradas às famílias está estipulado em normativo legal e é associado ao rendimento familiar per capita, podendo variar entre 26 e 304,50 euros. Nas entidades lucrativas, aplicam-se valores, em regra, fixos e mais elevados, decorrendo da oferta e da procura.
} 
gratuito às creches, põe em causa o direito das crianças a este bem socioeducativo, bem como fragiliza a igualdade de acesso da mulher ao mercado do trabalho. Por outro lado, as crianças pequenas ainda não estão no centro das prioridades da definição das políticas educativas, na medida em que o que se continua a esboçar são justificações políticas ligadas aos problemas sociais, como a conciliação do trabalho com a vida familiar e com o decréscimo da natalidade.

\section{Jardins de infância}

Após a publicação da Lei Quadro, a estratégia de expansão adotada pelo Estado passou pela mobilização das instituições do terceiro setor através da contratualização e do reforço das parcerias. Estas integraram a rede nacional e foram consideradas complementares à rede pública do ME. Os dados disponíveis dão conta de um aumento de $15,3 \%$ na taxa de frequência das crianças:

Tabela 1 - Taxa real de escolarização na educação pré-escolar em Portugal.

\begin{tabular}{|c|c|c|c|c|}
\hline Ano Letivo & 2000-2001 & 2010-2011 & 2015-2016 & 2017-2018 \\
\hline$\%$ & 74,8 & 85,7 & 88,4 & 90,1 \\
\hline
\end{tabular}

Fonte: Adaptado de Direção-Geral de Estatísticas da Educação e Ciência [DGEEC] (2017, 2019).

Ao olhar para a distribuição pelo território, observa-se que a taxa de escolarização é menor na área metropolitana de Lisboa e é maior na região autônoma da Madeira.

Tabela 2 - Taxa real de escolarização na educação pré-escolar em Portugal, por NUTS I e II, no ano letivo $2017 / 2018$.

\begin{tabular}{|c|c|c|c|c|c|c|c|c|}
\hline $\begin{array}{c}\text { NUTS I } \\
\text { II } \\
\text { \% }\end{array}$ & Norte & Centro & $\begin{array}{c}\text { A.M. } \\
\text { Lisboa }\end{array}$ & Alentejo & Algarve & Açores & Madeira & PORTUGAL \\
\hline & 94,6 & 93,9 & 81,8 & 95,3 & 92,7 & 90,1 & 96,6 & 90,1 \\
\hline
\end{tabular}

Fonte: DGEEC (2019: 29).

AM: Área metropolitana; NUTS: Unidades territoriais para fins estatísticos.

No PEDEPE (1997), as metas traçadas para a expansão da oferta apontavam para que, até ao fim do século XX, a oferta global da EPE fosse a seguinte: crianças de 5 anos - 90\%; de 4 anos $75 \%$; e de 3 anos - 60\%. Estas metas não se concretizaram naquele período, mas duas décadas mais tarde. No ano letivo de 2017/2018, a distribuição por idades era a seguinte: 5 anos - 94,0\%; 4 anos 93,1\%; e 3 anos - 82,8\% (DGEEC, 2019: 28). Este crescimento foi lento e não é uniforme em relação à idade, ilustrando a diferenciação etária como critério para a definição da política e como prioridade para o acesso. No ano letivo 2017/2018, estavam inscritas 240.231 crianças na Rede Nacional de EPE (DGEEC 2019: 22).

Os dados das tabelas 3 e 4 mostram que, nas últimas décadas, as duas redes têm crescido, verificando-se um maior aumento no que se refere à rede pública, embora com pouca expressão.

Tabela 3 - Alunos matriculados na educação pré-escolar em Portugal, por natureza do estabelecimento de ensino.

\begin{tabular}{|c|c|c|c|c|}
\hline Ano Letivo & 2000-2001 & 2005-2006 & 2010-2011 & 2015-2016 \\
\hline Ensino & 117226 & 139412 & 143472 & 137573 \\
\hline
\end{tabular}




\begin{tabular}{|l|l|l|l|l|}
\hline Ensino Privado (n) & 118384 & 122590 & 132653 & 122277 \\
\hline
\end{tabular}

Fonte: Educação em números Portugal - 2017, Direção-Geral de Estatísticas de Educação e Ciência. Legenda: n-número de alunos.

A tabela seguinte permite analisar a presença das crianças nas sub-redes: pública, privada não lucrativa e privada lucrativa.

Tabela 4 - Crianças inscritas na educação pré-escolar em Portugal, por NUTS I e II, rede e natureza do estabelecimento de ensino, no ano letivo 2017/2018.

\begin{tabular}{|c|l|l|c|c|c|c|c|c|}
\hline $\begin{array}{c}\text { NUTS I e II } \\
\text { Ensino }\end{array}$ & Norte & Centro & $\begin{array}{c}\text { A.M. } \\
\text { Lisboa }\end{array}$ & Alentejo & Algarve & Açores & Madeira & TOTAL \\
\hline $\begin{array}{c}\text { Ensino } \\
\text { Público }\end{array}$ & 44841 & 26917 & 32081 & 9954 & 6452 & 4258 & 3032 & 127535 \\
\hline $\begin{array}{c}\text { Ensino } \\
\text { Privado } \\
\text { dependente do } \\
\text { Estado }\end{array}$ & 23893 & 17143 & 19605 & 5461 & 3240 & 1943 & 2549 & 73834 \\
\hline $\begin{array}{c}\text { Ensino } \\
\text { Privado } \\
\text { independente }\end{array}$ & 10016 & 3555 & 21938 & 1051 & 1791 & 511 & - & 38862 \\
\hline
\end{tabular}

Fonte: DGEEC (2019: 26).

AM: Área metropolitana; NUTS: Unidades territoriais para fins estatísticos.

O que estes dados permitem constatar é que a rede pública integra o maior número de crianças $(53,1 \%)$, seguida da rede privada não lucrativa $(30,7 \%)$ e da rede privada lucrativa $(16,17 \%)$. Uma primeira ilação a retirar é que $46,9 \%$ das crianças inscritas não frequentam a rede pública. Este número é expressivo e fragiliza o direito das crianças à EPE gratuita. Com a publicação da Lei-Quadro, o acesso gratuito à componente educativa na rede privada não lucrativa ficou formalmente assegurado, e a componente de apoio à família passou a ser comparticipada financeiramente pelas famílias na rede pública. Esta realidade introduz dificuldade nesta análise, uma vez que as fronteiras entre o público e o privado são muito tênues.

Podemos questionar até que ponto o jardim de infância público é gratuito, quando uma das suas componentes tem que ser paga? Apesar de, recentemente, os dados estatísticos da EPE passarem a diferenciar o número de inscritos nas duas redes privadas, ainda não conseguimos obter dados de quantas crianças frequentam apenas a componente letiva na rede não lucrativa e se aquela prescrição legal está a ser cumprida. Os Relatórios da Inspeção Geral da Educação e Ciência (IGEC), produto das ações inspetivas realizadas aos jardins de infância das instituições privadas de solidariedade social da rede privada solidária entre maio de 2013 e julho de $2016^{21}$, identificam problemas a esse nível: "A maioria destes jardins de infância apresentava incumprimentos, face ao consignado no atual quadro legislativo, (...) não garantiam a gratuitidade da componente educativa da educação pré-escolar" (IGEC, 2013:14). Esta inconformidade é sobretudo identificada com o pagamento de atividades que decorrem durante a componente educativa e que são desenvolvidas por prestadores de serviços educativos externos. Um outro problema é que "A duração e gratuitidade da componente educativa/letiva não são comunicadas aos encarregados de educação das crianças que frequentam estes jardins de infância” (IGEC, 2018:24).

\footnotetext{
${ }^{19}$ Cujo financiamento central é suportado em $50 \%$ ou mais por entidades públicas, ou cujo pessoal docente é pago por um organismo governamental. Rede privada não lucrativa.

${ }^{20}$ Cujo financiamento central é suportado em menos de $50 \%$ por entidades públicas, ou cujo pessoal docente não é pago por um organismo governamental. Rede privada lucrativa.

${ }^{21}$ Nestas ações foram inspecionados 178 jardins: 26 em 2013 (Relatório Intercalar, 2013), 35 em 2014 (Relatório Global, 2014), 71 no ano letivo de 2014/2015 (Relatório Global, 2016) e 46 em 2015/2016, e foram feitas ações de continuidade a 120 (Relatório Global, 2018).
} 
Os dados obtidos expressam uma expansão que está aquém da procura e da garantia dos direitos da criança à educação de infância de qualidade. Houve um crescimento progressivo das duas redes, pública e privada, mas as assimetrias regionais ainda se observam com alguma expressão.

\section{Tensões na (re)definição da Educação de Infância: curricularização, neomeritocracia e colonização}

Em Portugal, a crescente visibilidade da importância da EPE como fator de promoção do sucesso educativo, da igualdade de oportunidades educativas e a sua definição como primeira etapa da Educação Básica faz com que este nível de educação não seja ignorado nos discursos da qualidade e de avaliação das escolas. Apesar do corpo legislativo regulador da qualidade e do conjunto de publicações de apoio, importa adotar uma vigilância crítica, dado que são múltiplos os fatores, interesses e sentidos que estão associados aos discursos da qualidade e da avaliação das instituições educativas.

Consideramos que as novas OCEPE (2016) surgiram em "contraciclo" ao momento atual, uma vez que nele se observa uma tendência internacional de (re)definição dos objetivos e finalidades da EI (Garnier, 2016) influenciada pelas políticas neoliberais que introduzem lógicas competitivas, seletivas, de mercado e de quase-mercado educacional (Le Grand, 1996).

Aquela tendência internacional tem acentuado a pré-escolarização, sendo visível na adoção de perspetivas pedagógicas e curriculares próximas da norma escolar, que enfatizam o ensino formalizado em conteúdos, sobrevalorizam a numeracia, a literacia e a ciência, a estandardização dos materiais pedagógicos e a avaliação das aprendizagens ${ }^{22}$. As OCEPE assumem a função educativa da EPE, apontam uma abordagem holística do currículo, assumem como princípios que a aprendizagem e o desenvolvimento são indissociáveis e valorizam o brincar e a criança como sujeito ativo e participativo. No entanto, o capítulo Continuidade Educativa e Transições introduz uma tensão entre esta orientação e a da pré-escolarização. Apesar de estar clarificado que "apoiar a transição e assegurar a continuidade não significa antecipar as metodologias e estratégias consideradas próprias da fase seguinte" (OCEPE: 97), a integração deste capítulo e a valorização da transição para o $10^{\circ}$ ciclo do ensino básico e da sequencialidade educativa, articuladas com a presença de áreas de conteúdos, têm potenciado leituras e apropriações diversas decorrentes das perspetivas, aspirações, interesses dos diferentes intervenientes: governantes, diretores (do público e do privado), educadores, professores, famílias e empresas.

Estas leituras têm permitido e justificado a entrada de racionalidades político-pedagógicas que conflituam entre si, que se espelham em práticas educativas e organizacionais que põem em causa a identidade e a especificidade curricular da EPE. Como referem Ferreira e Tomás (2018), aquela valorização tem disseminado, nos jardins de infância públicos e privados portugueses, a curricularização das práticas pedagógicas, orientadas para uma crescente intensificação da escolarização das crianças e a emergência da criança como aluno pré-escolar. À construção desta tendência não é também alheia a seletividade do sistema educativo, as formas de aferição dos resultados (exames nacionais, ao longo dos ciclos do ensino básico e no ensino secundário) e de publicitação dos mesmos, que têm vindo a potenciar o efeito de pressão em cadeia de cima para baixo, subvertendo o princípio curricular de articulação sequencial progressiva entre ciclos.

Outras fontes de pressão são o reinvestimento do capital cultural (Bourdieu \& Passeron, 1962), o assegurar a raridade (Nogueira, 2010) observado nas estratégias familiares das classes média e alta, que tendem a estar mais atentas ao que se ensina do que ao que se educa na EPE. Neste entendimento, o tempo de permanência nos jardins de infância terá de ser mais útil, mais ajustado às exigências de aquisição de conhecimentos "aplicáveis" e mobilizáveis no $1^{\circ}$ ciclo. Esboça-se na procura da EPE o efeito da neomeritocracia (Afonso, 2017) que, segundo o autor, está fortemente identificada com a "utilidade do que se ensina e do que se aprende, congruente com a hipervalorização dos projetos individuais, e muito em razão das pressões familiares, das supostas exigências de formação do capital humano e das

\footnotetext{
${ }^{22}$ Recordamos a ideia defendida no Relatório Early Learning and Well-being Study da OCDE, em que se defende que avaliar as crianças com 5 anos pode ter efeito na melhoria do seu desempenho nos testes PISA.
} 
lógicas do novo espírito do capitalismo" (id, 2018:332). Neste quadro, insere-se ainda a fabricação da necessidade do uso de manuais e de fichas de trabalho, que é construída pelas pressões do mercado editorial e materializada na oferta de pacotes preparados para consumir pelas crianças e educadores.

Associa-se a estas realidades o fato de os jardins de infância da rede pública estarem integrados em Agrupamento de Escolas $(\mathrm{AE})^{23}$, sendo estes sujeitos a avaliação externa. Esta integração trouxe vantagens organizativas e condições de melhoria da qualidade da oferta, mas também ampliou a possibilidade de se constituir como uma ameaça à especificidade curricular e à autonomia pedagógica da EPE. Temos observado a introdução (ainda que com expressão e intensidade diversas) de modos de gestão pedagógica marcados por influências e pressões internas e externas. Como refere Afonso (2018: 330 ),

\begin{abstract}
é muito provável que os diretores das escolas públicas, enquanto gestores públicos, tenham uma constante preocupação (quando não obsessão) em atender às regulamentações legais, às exigências hierárquicas e às demandas sociais relativas aos processos de avaliação, prestação de contas e responsabilização (três pilares fundamentais da accountability) e se confrontem, em razão disso, com dilemas e tensões decorrentes das diversas pressões e expectativas, internas e externas, advindas de uma pluralidade de atores (individuais e coletivos).
\end{abstract}

Em alguns AE, observam-se processos de microgestão, orientados por uma racionalidade burocrática uniformizadora, que põem em causa a conceção holística de gestão do currículo e a avaliação para as aprendizagens, preconizadas pelas OCEPE. Estamos a referir-nos à presença de registro obrigatório de sumários de "aulas" (diários e por "turma"), de horários com manchas de tempo destinadas a cada área de conteúdo e de instrumentos de avaliação estandardizados das crianças com enfoque nas aprendizagens. Um outro aspecto é a "oferta" (que se impõe) de projetos/programas/concursos da iniciativa de entidades privadas, de municípios, de organismos estatais e de fundações, não integrados no projeto educativo do AE e que, em alguns casos, propõem o alargamento do conteúdo curricular. Veja-se o exemplo do Plano Nacional de Formação Financeira, criado em 2012, pelo Conselho Nacional de Supervisores Financeiros e pelo Banco de Portugal ${ }^{24}$.

No que concerne aos jardins de infância da rede privada, a tradição dominante de serviço de apoio à família tornou-os estruturalmente mais capazes para dar uma melhor resposta social do que educativa. Daí que as pressões internas (dos proprietários/dirigentes associativos) tendem a ser menos centradas nos aspetos educativos do que nos relacionados com o serviço social de apoio às famílias (bons espaços, bom atendimento global, boa alimentação, horários alargados etc.). Apesar de a Lei-Quadro impor o cargo de diretor pedagógico, este nem sempre existe ou está reconhecido pelo Ministério da Educação, e muitas vezes não tem autonomia para tomar decisões previstas na lei. Como revelam os Relatórios da Inspeção-Geral da Educação e Ciência (IGEC) das ações inspetivas realizadas a jardins de infância da rede privada solidária, "Ao cargo de diretor pedagógico não é conferida, muitas vezes, no estabelecimento de educação pré-escolar, a relevância educativa que decorre das competências que lhes estão legalmente atribuídas" (Inspeção-Geral da Educação e Ciência [IGEC] 2018: 24). Por outro lado, ainda existe uma débil cultura de planeamento da ação educativa conjunta e de autoavaliação institucional no seio desta comunidade profissional, que a defenda de pressões internas e externas. Como se lê no mesmo Relatório da IGEC,

A avaliação para a regulação do processo educativo é um aspeto a merecer a atenção dos profissionais de educação. (...) O trabalho colaborativo tendo em vista o desenvolvimento profissional e melhoria das práticas docentes carece de maior investimento (ibidem: 25).

\footnotetext{
${ }^{23}$ Estrutura organizativa estatal que agrega os jardins de infância e as escolas dos ensinos básico e, por vezes, do secundário, de um determinado território.

${ }^{24}$ Através de um protocolo celebrado entre o Ministério da Educação e o Banco de Portugal, é proposto à Educação PréEscolar e aos Ensinos Básico e Secundário. Este Plano criou um conjunto de materiais e iniciativas: Referencial de Educação Financeira, Plano de formação para professores, concurso "Todos Contam” e o Dia da Formação Financeira. Educação em Revista|Belo Horizonte|v.36|e231420|2020
} 
Aqueles relatórios registram debilidades no planeamento da ação educativa e na organização do ambiente educativo, entre elas: as Orientações Curriculares, normativos, circulares e textos de apoio não são os referentes para a ação educativa (IGEC, 2018: 24); existem projetos pedagógicos e curriculares que não são sustentados na caracterização do grupo de crianças e nas dinâmicas do mesmo; uma abordagem curricular compartimentada em áreas; a utilização de fichas e de manuais; a prática educativa é tendencialmente centrada no educador, que limita o papel ativo da criança nas propostas de planificação, concretização e avaliação dos processos; a organização do ambiente que não apresenta diversidade, quantidade e qualidade adequada ao nível dos equipamentos e materiais pedagógicos (idem, 2014:10; 2018:25); e o não cumprimento do tempo educativo diário de cinco horas (idem, 2014, 2016, 2018). Esses problemas colocam em causa os fundamentos e princípios pedagógicos e a organização do ambiente educativo definidos pelas OCEPE e enunciam a presença de uma lógica curricular de pendor pré-escolarizante.

Todos os relatórios constataram ainda a presença de outros docentes/técnicos a orientarem atividades no período da componente educativa sem que estas fossem objeto de planeamento e avaliação dos processos com o educador titular do grupo. Para além de comprometerem a "dimensão holística desta componente e consequentemente a construção e o desenvolvimento do currículo" (IGEC, 2018:24), esta realidade expressa uma estratégia de marketing, de produção de fabricação/gestão da impressão (Ball, 2002) de qualidade destes jardins de infância, pois aqueles "novos colaboradores" são apresentados como especialistas e as atividades como sendo extracurriculares ${ }^{25}$, justificando assim o seu pagamento.

Esta realidade configura processos de mercantilização da educação de infância, que se legitimam na defesa da liberdade individual, da escolha parental e da qualidade do serviço prestado. A oferta educativa, particularmente a extracurricular, ganha o valor de mercadoria que se oferece no mercado educacional de forma distintiva em relação a outros jardins de infância, quer pelos seus recursos humanos, quer pela forma como os conteúdos são trabalhados (com apoio de livros e fichas estandardizados) ou ainda pela apologia de novas pedagogias (inovadoras, com recursos a novas tecnologias).

Assim, mesmo sendo estes jardins de infância não lucrativos, a necessidade de "angariar" e fidelizar "clientes" torna-os mais permeáveis às lógicas de mercado e à introdução acrítica de "modas", sejam elas de natureza pedagógica ou de organização e gestão. Por exemplo, a oferta da Certificação da Qualidade por diferentes agências (externas aos campos educativo e social) tem gerado a procura daquela certificação, que passa a ser entendida como um valor acrescentado para estas organizações. O selo da qualidade é exibido como mais um elemento distintivo, num mercado educacional cada vez mais competitivo, aumentado pelo decréscimo da natalidade e pela presença da Componente de Apoio à Família nos jardins de infância públicos, que passou a dar uma resposta mais adequada às necessidades das famílias que trabalham.

\section{A "nova governação" da EPE: parcerias e a diluição de fronteiras entre o público e o privado}

A grande mudança organizacional operada na EPE foi a adoção de um modelo integrado de educação e de apoio à família em todos os jardins de infância da rede nacional. No que concerne à rede pública, a estratégia adotada pelo governo para a implementação da Componente de Apoio à Família (CAF) passou pelo envolvimento dos municípios e de entidades da sociedade civil, através da celebração de protocolos de cooperação e da contratualização dos serviços. No protocolo, são definidas responsabilidades dos diversos parceiros, sendo da competência dos Municípios a operacionalização desta componente, no que diz respeito a espaços, recursos humanos e materiais. Esta estratégia de mobilização da comunidade introduziu maior complexidade na implementação e desenvolvimento desta componente, uma vez que nela passaram a participar novos intervenientes e provedores que têm

\footnotetext{
${ }^{25}$ Estas atividades são essencialmente nos domínios da língua inglesa, das expressões artísticas (música, ballet, expressão motora) e das novas tecnologias de informação.

Educação em Revista|Belo Horizonte|v.36|e231420|2020
} 
diferentes lógicas de ação, poderes, modos de socialização profissional e modos de organização do trabalho.

Neste tópico, suportamo-nos de alguns dados de um estudo de caso que analisou a implementação da CAF em jardins de infância públicos, realizado no período compreendido entre 2003 e 2010, no concelho de Mareantes ${ }^{26}$, situado no Norte de Portugal (Vilarinho, 2011), aos quais acrescentamos elementos recolhidos através da análise documental no âmbito da investigação em curso. A CAF introduziu maior complexidade organizacional aos jardins de infância da rede pública, alargou a possibilidade da participação da sociedade civil na implementação e governação da mesma e introduziu novos problemas.

O Município de Mareantes optou por delegar competências nas entidades das freguesias ${ }^{27}$. Esta opção promoveu a emergência da diversificação de modalidades e padrões de governação, levando à ocorrência do efeito de mosaico ${ }^{28}$ (cf. Barroso, 2003) naquele território. Apesar do empenho e vontade de todos, foram identificados alguns problemas, muitos deles decorrentes da frágil relação institucional e da ausência de mecanismos formais de regulação local. Verificamos, por exemplo, que no que diz respeito à coordenação da CAF, os educadores de infância estiveram muito tempo ausentes. Esta ausência foi tacitamente aceite pelos parceiros, tendo propiciado o desenvolvimento de serviços de qualidade variável que se traduziram em desigualdades de condições oferecidas às crianças, ao nível dos espaços, dos equipamentos, dos materiais pedagógicos e da quantidade e perfil dos profissionais.

A assunção daquela coordenação aparece gradualmente ao longo dos anos, à medida que os educadores de infância e os diretores de AE tomaram consciência profissional e institucional da sua importância. Será através do Despacho n. ${ }^{0}$ 14460/2008, de 26 de maio ${ }^{29}$, que os Agrupamentos de Escolas vão encontrar a justificação e legitimação para contrariar práticas das entidades parceiras, no que concerne à planificação das atividades de animação socioeducativa. A planificação e o desenvolvimento destas atividades pelas entidades parceiras, no espaço público, criaram ainda as condições para que lógicas do mercado educacional fossem entrando nas dinâmicas pedagógicas dos jardins de infância - ou seja, foram criadas as condições para os processos de privatização do conteúdo da educação de infância, por exemplo, com a introdução de atividades de natureza artística como o ballet, a música, a expressão físicomotora e outras atividades de natureza acadêmica, como o "ensino do inglês", desenvolvidas por professores, prestadores de serviços.

Esta realidade dá expressão a formas de privatização na educação de infância. Poderemos questionar até que ponto não estaremos na presença de uma certa "colonização" do privado, no sentido inverso ao referido por Mons $(2011)^{30}$, uma vez que aquelas atividades eram mais desenvolvidas nos jardins de infância da rede privada, como citamos no ponto anterior. Encontramos no espaço público a mesma racionalidade político-pedagógica encontrada nos jardins de infância privados solidários. A EPE tem cofinanciamento do Estado e das famílias, sendo que a comparticipação familiar só se aplica à frequência da CAF. Os mecanismos e instrumentos de financiamento estão regulamentados e plasmados no protocolo de cooperação celebrado entre os diferentes parceiros.

\footnotetext{
${ }^{26}$ Nome fictício. Neste estudo, utilizamos como técnicas de busca de informação a observação não participante, a análise documental e a entrevista semiestruturada. Identificamos os atores significativos e agrupamo-los em três grupos, tendo em conta o papel que cada grupo de atores assume na implementação das políticas. Foram entrevistados políticos regionais e autárquicos, presidentes nacionais das organizações do terceiro setor, diretores dos AE, presidentes de entidades locais parceiras na implementação da CAF.

27 Menor divisão administrativa de Portugal integrada num concelho/município.

${ }^{28}$ Este efeito tem sido definido com referência à existência de um conjunto de iniciativas e normas, com o fim de porem em prática processos de desregulação e privatização, comuns em vários países, que são usadas de forma avulsa em diferentes tempos e espaços. Daqui decorre que a "visão" que se tem da educação nesses países "corresponde mais à imagem de um "mosaico" de unidades isoladas do que à de um agregado coerente de elementos, interagindo entre si com o mesmo fim" (Barroso, 2003: 33).

${ }^{29}$ Define as normas a serem observadas na oferta das atividades de enriquecimento curricular e de animação e de apoio à família $\left(1^{\circ}\right.$ ciclo e EPE).

${ }^{30}$ Esta ideia decorre do que a autora tem referido relativamente ao crescimento do ensino privado. Para ela existe uma espécie de colonização do público nas escolas privadas, uma vez que estas são submetidas aos mesmos programas e a uma certa instrumentalização pelos poderes públicos.
} 
Nas entrevistas que nos concederam, os políticos regionais e os dirigentes das estruturas nacionais representativas da rede não lucrativa levantaram questões em relação aos diferentes procedimentos de atribuição da comparticipação familiar, adotados em diferentes municípios. A relevância deste assunto face aos seus efeitos, quer na consolidação das duas redes (pública e privada solidária), quer no que concerne à igualdade de acesso à EPE, fez-nos estar atentos a este aspecto ao nível local.

Relativamente à comparticipação estatal, os dados são objetivos: os valores elegíveis são transferidos para o Município que, por sua vez, transfere para as entidades parceiras. Em relação às comparticipações familiares, a busca de informação tornou-se muito difícil. O município não sabia que procedimentos as entidades parceiras estavam a adotar, apesar de o protocolo assinado entre ambos impor o cumprimento do Despacho Normativo Conjunto n. ${ }^{\circ} 300 / 97$. Da parte dos nossos entrevistados, verificamos que existiam muitas hesitações e imprecisões relativamente às comparticipações pagas pelas famílias. Pelo cruzamento de dados conseguimos apurar a realidade, constatando que: em 16 jardins de infância públicos, 10 aplicam um valor único; em 3 jardins existia uma tabela com seis escalões; um dos jardins tinha uma tabela com três escalões; e, num jardim de infância, as crianças pagavam as refeições pelo valor legalmente previsto, sendo gratuitas as atividades de animação.

Esta realidade configura inconformidade na aplicação da comparticipação familiar. O espírito da lei vai no sentido da discriminação positiva das crianças provenientes de famílias com rendimentos baixos. O valor único e mesmo os escalões atribuídos sem ter em conta a diferenciação por escalões de rendimento familiar per capita, prescrita no Despacho Normativo, são indicadores do desrespeito pelo princípio de discriminação positiva. Este fato levanta questões em relação à igualdade de acesso das crianças à frequência da EPE. Os responsáveis pelas entidades parceiras, bem como os diretores dos AE revelaram não ter consciência dos efeitos produzidos e afirmam que há concordância por parte dos pais. Muitas vezes, este acordo obtém-se através de formas aparentemente democráticas: "Na reunião de pais do início do ano, a associação põe a votação se os pais querem pagar todos o mesmo" (educadora, JI B).

O que está a acontecer (com expressão desigual entre municípios) é que as crianças provenientes de famílias economicamente mais desfavorecidas estão a ser penalizadas em relação às crianças das classes média e média-alta. Ora, este fato introduz um efeito de $2^{a}$ ordem, (Ball, 2004) não esperado e perverso, podendo ser uma das razões explicativas da procura da classe média pelos jardins de infância da rede pública e da transferência das crianças da rede solidária para a pública. Como disse o dirigente da entidade parceira do jardim de infância de Astrolábio 31 , "algumas crianças estavam em privados, vieram para aqui" (EPA).

Tentando compreender por que tal situação acontece, consideramos ser possível justificá-la pela presença de um conjunto de processos de multiregulação local (Barroso, 2003) que se anulam entre si. Por outo lado, o fato de o governo autárquico não assumir "a coordenação da governação" (Dale, 2005) da CAF de Mareantes e de a sua presença neste processo ser muito frágil favoreceu a presença deste efeito - desiguais condições de acesso em função dos rendimentos familiares. Por outro lado, consideramos que esse efeito é também justificável pela ausência de uma análise política do texto da lei.

$\mathrm{Na}$ pesquisa em curso, os dados recolhidos até ao momento indicam que no Município de Mareantes este problema se mantém, e cinco vereadores de educação de outros concelhos da região norte referiram que não têm informação sobre a forma como o despacho normativo está a ser aplicado: "julgo que aplicarão o normativo, mas não tenho informação concreta" (VE2), "não sei, mas era importante saber" (VE4). Observou-se que alguns municípios são os promotores diretos da CAF e assumem a sua implementação, e outros contratualizam com empresas o desenvolvimento das atividades socioeducativas. Em Mareantes, passou a ser aplicada na EPE pública a regulamentação da ação social escolar, lei n. ${ }^{\circ} 55 / 2009$ de 2 de março $^{32}$, no que concerne às refeições escolares e, por decisão do governo

\footnotetext{
${ }^{31}$ Nome fictício.

${ }^{32}$ Determina que os apoios ao nível da ação social escolar também se aplicam à EPE. Os apoios são ao nível das refeições, dos manuais e materiais escolares e do transporte escolar. Estes são definidos em função do nível do abono de família que está indexado ao seu rendimento familiar. Assim, às famílias de rendimento muito baixo é atribuído o Escalão A Educação em Revista|Belo Horizonte|v.36|e231420|2020
} 
municipal, foi alargada sua aplicação à rede privada não lucrativa. Este elemento é interessante, quer porque ilustra uma orientação de democratização do acesso, quer ainda porque materializa um novo "arranjo institucional" na implementação da política educativa local.

\section{CONSIDERAÇÕES FINAIS}

Em Portugal ainda não há uma Política de Educação de Infância, mas políticas de educação de infância. Estas são marcadas pelo recorte da primeira infância (0-3 e 3-6 anos), que tem influenciado a definição da função social das creches e dos jardins de infância, as suas finalidades e as modalidades de expansão da oferta. O atendimento das crianças dos 0 aos 3 anos não é integrado na Lei de Bases do Sistema Educativo, perpetuando a finalidade social de apoio às famílias em detrimento da função educativa e do direito da criança à educação e a cuidados de forma integrada. As crianças desta faixa etária não têm assegurado o direito de acesso a uma creche pública gratuita, uma vez que se mantém a privatização das creches. O Estado não assume o papel de promotor da oferta, mas incentiva, através de parcerias e de programas de apoio à construção de equipamentos, a expansão da rede privada não lucrativa. A regulação da rede de creches tem fragilidades que são visíveis nas assimetrias territoriais da oferta do privado lucrativo e do privado não lucrativo e que beneficia a lei da oferta e da procura.

Apesar de se observar um investimento na expansão da rede de jardins de infância, e as taxas de pré-escolarização terem aumentado, ainda não está garantida a gratuitidade de acesso. É ainda expressivo o número de crianças inscritas na rede privada (46,9\%). Têm surgido novas desigualdades, decorrentes da não gratuitidade da Componente de Apoio à Família nos jardins de infância públicos e das dificuldades de admissão na componente educativa das IPSS, criadas quer por incompatibilidade dos horários laborais das famílias, quer por dinâmicas organizacionais desta rede. Continua a existir uma tendência para a despolitização do debate em torno da ausência de uma rede de Educação de Infância (0-6 anos) e da natureza das redes de creches e de jardins de infância existentes, já que nele não se tem contemplado a problematização das suas implicações na concretização do direito à educação de qualidade e respeitadora da cidadania da criança.

Relativamente às finalidades e ao conteúdo da EPE, o discurso político e algumas práticas da administração local da educação (pública e privada) mais recentes incorporam novos sentidos que evidenciam a influência dos processos de globalização, da transnacionalização da educação e de regulação pelos resultados, que as organizações internacionais (OCDE, BM, FMI) têm potenciado. Aqueles sentidos são visíveis na tendência de "escolarizar" a EPE enquanto estratégia de promoção da melhoria dos resultados escolares a serem alcançados pelas crianças nos níveis subsequentes. Consideramos, provisoriamente, que a integração dos jardins de infância públicos nos Agrupamentos de Escolas tem potenciado a proximidade a esta tendência.

Em suma, as políticas de educação de infância espelham hibridismos, tensões, contradições (nos discursos e nas práticas) resultantes das políticas de pendor democratizante e gerencialista que têm influenciado a definição das políticas públicas portuguesas (Afonso, 1998, 2018; Antunes \& Peroni, 2017; Barroso, 2003, 2017). Aqueles hibridismos e tensões observam-se, por exemplo: i) na política de universalização da oferta, que tende a alargar e democratizar o acesso, mas em que, não sendo o Estado o único provedor, se verifica a permeabilidade à introdução de lógicas de mercado; ii) na coexistência de uma componente gratuita e outra comparticipada pelas famílias no mesmo estabelecimento e na qual se observam fragilidades de regulação estatal no cumprimento dos normativos; iii) na constituição de parcerias na implementação da Componente de Apoio à Família nos jardins de infância públicos que potenciam a presença de diferentes lógicas e interesses (os das crianças, das famílias, das entidades parceiras e dos municípios), tendencialmente conflituantes, que condicionam a qualidade do serviço prestado e permitem a introdução de lógicas de mercado educacional; iv) na disputa pelo conteúdo da educação de infância a partir de racionalidades político-pedagógicas que conflituam entre si, como a das

(comparticipação de 100\% do custo) e às de rendimento médio-baixo, o Escalão B (50\% do custo). O transporte escolar é gratuito se a residência do aluno for a mais de $3 \mathrm{Km}$ da escola. Todavia, a ausência da regulamentação da sua operacionalização para este nível de educação e a não revogação do Despacho n. ${ }^{\circ}$ 300/97 leva a que existam municípios que não a apliquem. Educação em Revista|Belo Horizonte|v.36|e231420|2020 
Orientações Curriculares que reforçam a especificidade educativa da EPE, uma abordagem holística do currículo e a cidadania das crianças, e a que valoriza a pré-escolarização com o ensino formalizado em conteúdos e que decorre da influência de lógicas mais competitivas de construção de um percurso individual academicamente bem-sucedido.

$\mathrm{Na}$ concretização daquelas políticas, são visíveis as influências das orientações de inspiração neoliberal, da nova gestão pública (Hood, 1991) e da terceira via (Giddens, 1999; Vilarinho, 2011) que revalorizaram (em sentidos vários) os apelos e as medidas direcionadas para uma maior participação do mercado, da sociedade civil e do terceiro setor nas políticas públicas. Elas ilustram ainda como, em particular na implementação da Lei-Quadro da EPE, "a antinomia público/privado foi substituída por um continuum de articulações e de parcerias" (Lima, 2018: 130) que reinventam o "governo da coisa pública" (ibidem), que envolvem múltiplos e novos provedores e que diluem as fronteiras entre o público e o privado (Antunes \& Peroni, 2017). Os dados recolhidos documentam um universo educacional de fronteiras movediças, no qual, pela contratualização e pelas parcerias estabelecidas, se introduzem modalidades de privatização na educação de infância pública.

\section{REFERÊNCIAS}

Afonso, A. J. (1988). Políticas educativas e avaliação educacional. Para uma análise sociológica da reforma educativa em Portugal (1985-1995). Braga: Universidade do Minho.

Afonso, A. J. (2017). Neomeritocracia e novas desigualdades - breves comentários. In L. L. Torres, \& J. A. Palhares (Orgs.), A excelência na escola pública portuguesa (pp. 253-263). V. N. de Gaia: Fundação Manuel Leão.

Afonso, A. J. (2018). O diretor enquanto gestor e as diferentes pressões e dilemas da prestação de contas na escola pública. Roteiro, Edição Especial, 327-344. Recuperado de:

http://dx.doi.org/10.18593/r.v0i0.17538.

Antunes, F., \& Peroni, V. (2017). Reformas do Estado e políticas públicas: trajetórias de democratização e privatização em educação. Brasil e Portugal, um diálogo entre pesquisas. Revista Portuguesa de Educação, 30(1), 181- 216.

Bairrão, J., Leal, T., \& Gamelas, A. M. (1999). Educação pré-escolar em Portugal - Estudo de qualidade. Porto: Faculdade de Psicologia e de Ciências da Educação Universidade do Porto.

Ball, S. (2002). Reformar as escolas/reformar professores e os terrores da perfomatividade. Revista Portuguesa de Educação, 15(2), 3-23.

Ball, S. (2004). Performatividade, Privatização e o Pós-Estado do Bem-Estar. Educação \& Sociedade, 25, (89), 1105-1126.

Barroso, J., (2003). "Regulação e desregulação nas políticas educativas: tendências emergentes em estudos de educação comparada" in J. Barroso (org.). A Escola Pública. Regulação. Desregulação. Privatização (pp. 19-48). Porto: ASA Edições.

Barroso, J., (2017). Centralização, descentralização, autonomia e controlo. In L. Lima \& V. Sá (Org.), O Governo das Escolas. Democracia, controlo e perfomatividade (pp.23-40). V.N. Famalicão: Edições Húmus.

Bassok, D. \& Latham, Scott \& Rorem, Anna. (2016). Is Kindergarten the New First Grade?. AERA Open. 2. $10.1177 / 2332858415616358$. 
Bertram, A., \& Pascal, C. (1997). A conceptual Framework for Evaluating Effectives in Early Childhood Education. In M. K. Lohmander (ed.). Researching Early Childhood (pp. 125-150), vol.3. Sweden: University of Göteborg.

Bourdieu, P., \& Passeron, P.C. (1964). Les Héritiers. Les étudiants et la culture. Paris: Editions de Minuit.

Bowe, R., Ball, S. J., \& Gold, A. (1992). The Policy Process and the process of policy. In R. Bowe \& S. J. Ball (Orgs.), Reforming, Education and Changing Schools. Case Studies in Policy Sociology (pp. 6-23). Londres: Routledge.

Chamboredon, J. C \& Prévot, J. (1982). "O Ofício da Criança” in R. Grácio; S. Stoer \& S. Miranda (orgs.). Sociologia da Educação II - A Construção Social das Práticas Educativas. (pp. 51-77). Lisboa: Livros Horizonte.

Conselho Nacional de Educação (1994). Parecer n. ${ }^{\circ} 1 / 94$ do Conselho Nacional de Educação sobre Educação Pré-Escolar em Portugal. Lisboa: CNE.

Conselho Nacional de Educação (2011). Recomendação n. ${ }^{0}$ 3/2011. A Educação dos 0 aos 3 anos. Lisboa: CNE.

Dahlberg, G., Moss, P., \& Pence, A. (2003). Qualidade na Educação da Primeira Infância. Perspetivas pósmodernas. Porto Alegre: ARTMED.

Dale, R. (2005). A globalização e a reavaliação da governação educacional: um caso de ectopia sociológica. In A. Teodoro \& C. A. Torres (Orgs.), Educação crítica e utopia: perspectivas para o século XXI (pp.53-69). Porto: Afrontamento.

Direcção-Geral da Ação Social (1996). Guião Técnico nº 4 - Creche. Lisboa: DGAS - Núcleo de Documentação Técnica e Divulgação. Recuperado de: http://www.segsocial.pt/documents/10152/39853/Creche/5079ba10-4e6e-4484-861b-86ea2fab1ef5.

Direção-Geral de Estatísticas da Educação e Ciência (2017). Educação em Números - Portugal 2017 Lisboa: Direção-Geral de Estatísticas da Educação e Ciência. Recuperado de: http://www.dgeec.mec.pt/np4/827.html.

Direção-Geral de Estatísticas da Educação e Ciência (2019). Educação em Números - Portugal 2019. Lisboa: Direção-Geral de Estatísticas da Educação e Ciência. Recuperado de: http://www.dgeec.mec.pt/np4/1031.html.

Fernandes, N. (2009). Infância, direitos e participação. Representações, Práticas e Poderes. Porto: Edições Afrontamento.

Ferreira, M.; Tomás, C. (2018). “O pré-escolar faz a diferença?” Políticas educativas na educação de infância e práticas pedagógicas. Revista Portuguesa de Educação, 31(2), pp. 68-84. DOI:

$10.21814 /$ rpe.14142.

Halldén, G. (2012). Children's sense of place. Aspects of individualization, flexibility and free choice within the preschool context. In A. T. Kjorholt \& J. Qvortrup (Eds) The Modern Child and the Flexible Labour Market Early Childhood Education and Care (pp. 186-202). London: Palgrave Macmillan. 
Inspeção-Geral da Educação e Ciência (2013). Jardins de Infância da Rede Privada. Instituições Particulares de Solidariedade Social. Relatório intercalar. Lisboa: Inspeção-Geral da Educação e Ciência.

Inspeção-Geral da Educação e Ciência (2014). Jardins de Infância da Rede Privada - Instituições Particulares de Solidariedade Social. Relatório Global. Lisboa: Inspeção-Geral da Educação e Ciência.

Inspeção-Geral da Educação e Ciência (2016). Jardins de Infância da Rede Privada — Instituições Particulares de Solidariedade Social-Relatório global. Lisboa: Inspeção-Geral da Educação e Ciência.

Inspeção-Geral da Educação e Ciência (2018). Jardins de Infância da Rede Privada - Instituições Particulares de Solidariedade Social. Relatório global 2015-2016. Lisboa: Inspeção-Geral da Educação e Ciência.

Gabinete de Estratégia e Planeamento/Ministério do Trabalho, Solidariedade e Segurança Social (2019). Carta Social - Rede de Serviços e Equipamentos 2018. Lisboa: GEP/MTSSS. Recuperado de: http://www.cartasocial.pt/pdf/csocial2018.pdf.

Garnier, P. (2016). Sociologie de l'école maternelle. Paris: PUF.

Giddens, A. (1999). Para uma terceira via. Lisboa: Editorial Presença.

Hendrix, H. (1990). "Constructions and Reconstructions of British Childhood: An Interpretative Survey, 1800 to the Present" in A. James \& A. Proust. (Ed) A. Constrtucting and Reconstructing Childhood: Contemporany Issues. In the sociological study of Childhood pp. 35-59. London: The Falmer Press.

Hood, C. (1991) A public management for all seasons?. Public administration, 69(1), 3-19.

Le Grand, J. (1996). Los quasi mercados y la politica social. In E. Oral, (Org.), Economía de la educación (pp. 257-271). Barcelona: Ariel.

Lima, L. C. (2018). Privatização lato sensu e impregnação empresarial na gestão da educação pública. Currículo sem Fronteiras, 18(1), 128-144.

Losso, C., \& Marchi, R. (2011). A construção social do "ofício de aluno" na educação infantil. Atos de Pesquisa em Educação, 6(3), 603-631.

Marchi, R., \& Sarmento, M. J. (2017). Infância, Normatividade e Direitos das Crianças: Transições Contemporâneas. Educação \& Sociedade, 38(141), 951-964.

Nasman, E. (1994). Individualization and institutionalization of children. In J, Qvortrup; M. Bardy; G. Sgritta; H. Wintersberger (Eds.), Childhood matters: social theory, practice and politics. Aldershot: Avebury.

Mons, N. (2011). Privatisation sous haute surveillance étatique: une comparaison international. In Y. Dutercq (Dir.), Où va l'education entre public et privé? (pp. 19-35). Bruxelles: Éditions De Boeck Université.

Nogueira, M. A. (2010). Classe média e escola: Novas perspetivas de análise. Currículo sem Fronteiras, 10(1), 213-231.

Portugal/Ministério da Educação (1993). Plano de Desenvolvimento a Quatro Anos da Educação Pré-Escolar. Lisboa: ME [policopiado]. 
Portugal/Ministério da Educação (1996). Relatório Estratégico para a Expansão e Desenvolvimento da Educação Pré-Escolar. Lisboa: ME [policopiado].

Prout, A. (2010). Participação, políticas e as condições da infância em mudança. In F. Müller (Org.). Infãncia em Perspectiva. Políticas, Pesquisas e Instituições (pp.21-41). São Paulo: Cortez Editora.

Stoer, S. (1986). Educação e Mudança Social em Portugal. 1970-1980, Uma Década de Transição. Porto: Edições Afrontamento.

Vilarinho, E. (2000). Políticas de Educação Pré-Escolar em Portugal (1977/ 1997). Lisboa: Instituto de Inovação Educacional.

Vilarinho, E. (2011). O Estado e o Terceiro Sector na Construção das Políticas Educativas para a Infância em Portugal: o caso da Educação Pré-Escolar (1995-2010). Braga: Universidade do Minho [Tese de

Doutoramento].

Vilarinho, E. (2015). Pela "causa" da educação pré-escolar em Portugal: aproximações às políticas de Terceira Via. In V. Peroni (Org.), Diálogos sobre as redefiniçoes no papel do Estado e nas fronteiras entre o público e o privado em Educação (pp. 144-174). São Leopoldo: Oikos.

Submetido: $15 / 11 / 2019$

Aprovado: $10 / 07 / 2020$ 